\title{
The African Church's application of anointing oil: An expression of Christian spirituality or a display of fetish ancestral religion?
}

\begin{tabular}{|c|c|}
\hline $\begin{array}{l}\text { Author: } \\
\text { Joel K.T. Biwu }\end{array}$ & \\
\hline $\begin{array}{l}\text { Affiliations: } \\
{ }^{1} \text { Department } \\
\text { Studies, Facul } \\
\text { ECWA Theolo } \\
\text { Jos, Nigeria }\end{array}$ & $\begin{array}{l}\text { of Biblical } \\
\text { ty of Theology, } \\
\text { gical Seminary, }\end{array}$ \\
\hline $\begin{array}{l}{ }^{2} \text { Department } \\
\text { New Testame } \\
\text { of Theology, } \\
\text { University, Ca } \\
\text { South Africa }\end{array}$ & $\begin{array}{l}\text { of Old and } \\
\text { nt, Faculty } \\
\text { tellenbosch } \\
\text { pe Town, }\end{array}$ \\
\hline $\begin{array}{l}\text { Correspondin } \\
\text { Joel Biwul, } \\
\text { biwuljetschol }\end{array}$ & $\begin{array}{l}\text { g author: } \\
\text { ar@gmail.com }\end{array}$ \\
\hline $\begin{array}{l}\text { Dates: } \\
\text { Received: } 22 \mathrm{~J} \\
\text { Accepted: } 22 \\
\text { Published: } 28\end{array}$ & $\begin{array}{l}\text { uly } 2020 \\
\text { Oct. } 2020 \\
\text { Jan. } 2021\end{array}$ \\
\hline $\begin{array}{l}\text { How to cite th } \\
\text { Biwul, J.K., } 20 \\
\text { Church's appli } \\
\text { anointing oil: } \\
\text { of Christian sp } \\
\text { display of fetis } \\
\text { religion?', HTs } \\
\text { Studies/Theol } \\
77(4), \text { a6266. } \\
\text { org/10.4102/l }\end{array}$ & $\begin{array}{l}\text { is article: } \\
21, \text { 'The African } \\
\text { cation of } \\
\text { An expression } \\
\text { irituality or a } \\
\text { sh ancestral } \\
5 \text { Teologiese } \\
\text { ogical Studies } \\
\text { https://doi. } \\
\text { hts.v77i4.6266 }\end{array}$ \\
\hline $\begin{array}{l}\text { Copyright: } \\
\text { @ 2021. The } \\
\text { Licensee: AOS } \\
\text { is licensed un } \\
\text { Creative Com } \\
\text { Attribution Lic }\end{array}$ & $\begin{array}{l}\text { Uthors. } \\
\text { IS. This work } \\
\text { der the } \\
\text { nons } \\
\text { ense. }\end{array}$ \\
\hline Read online: & \\
\hline 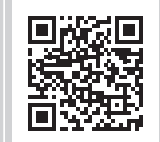 & $\begin{array}{l}\text { Scan this QR } \\
\text { code with your } \\
\text { smart phone or } \\
\text { mobile device } \\
\text { to read online. }\end{array}$ \\
\hline
\end{tabular}

The content of Christian spirituality that made waves since the inception of the early church soon took on different contours as the faith got adapted to different gentile contexts. The expression of this faith, along with its liturgical symbolism and sacramental observances, is still gaining momentum in African Christianity. The emerging practice of the use of 'anointing oil' in its religious expression is receiving more attention than the Christ of the Gospel. In this article, we argue that against its primitive intent, the use of the 'anointing oil' by the African Church is a mere display of fetish ancestral religion that expresses its unique African traditional religious root rather than a true expression of Christian spirituality. Our thesis is framed on the basis that the manner in which some African churches apply the purported 'anointing oil' is discriminatory vis-à-vis its ancient understanding and purpose. In our attempt to address this damaging practice to true Christian spirituality, also standing as a huge challenge for pastoral theology, we undertook a careful historical-theological analysis of the extant biblical data and its contextual interpretation vis-à-vis its distortion today. We concluded that what pastoral theologians have to deal with within the Christian community in Africa is offering the right biblical perspective against the distorted mode of the application of the contemporary purported 'anointing oil' that is falsely projecting the Christian faith and belief in a bad light.

Contribution: The application of the anointing oil in contemporary Christian religion in Africa is, to say the least, not an inherent textually prescribed requisite criterion for Christian spirituality, but merely an outburst of fetish ancestral religious worldview that stands contra the hermeneutics of the biblical text and its ancient tradition. That no Old Testament prophet, not even Jesus nor Paul, mentioned the subject, makes its contemporary application textually and theologically suspect, and therefore, heretically infectious for the spiritual health of the community of faith. These insights sit quite well with the textual hermeneutics within the mainline transdisciplinary religious and multidisplinary theological perspective of this journal.

Keywords: African church; African Christianity; ancestral religion; anointing oil; Christian spirituality; Jewish tradition; pastoral theology.

\section{Introduction}

The reality of oil and its various uses, such as for domestic, sociocultural and socio-economic purposes, have been with humanity since antiquity (Gn 1:29; 9:3; 28:18; 35:14). Oil still has and will continue to have social and economic values in human societies. However, the ancient conceptualisation of the nature, essence, purpose and the method of applying what was designated the sacred 'anointing oil' in Jewish tradition, put pari passu the contemporary perception, has conflicting nuances, thereby becoming detrimental to the Christian faith. According to the biblical data, the sacred 'anointing oil' in Jewish understanding was quite different from ordinary oil; the former was used strictly for cultic and politically related purposes, whilst the latter was destined for general purposes. By this, this article presupposes that contemporary African Christianity desecrates and disastrously distorts the initial primary essence and intention for applying the sacred 'anointing oil'. Accordingly, the claim to and manner in which the purported oil is used, supposedly as an expression of Christian spirituality, is perjurious vis-à-vis the ancient purpose.

The following queries seek to validate our thesis: how different was the sacred 'anointing oil' from other categories of oil in antiquity or Jewish society? How did the ancients understand the distinction, nature, essence and purpose of the sacred 'anointing oil' and its efficacy? What was the prescribed method for its application and who qualified both to apply and benefit from it? Does the manner in which the purported 'anointing oil' being used today within the circle of 
some African Christian communities portray a true reflection of its original intent; and is its application a true portrayal of Christian spirituality, or is it a mere display of fetish ancestral religion? What theological implications does such erroneous practice portend for true Christian spirituality and pastoral theology in Africa?

In an attempt to respond to these queries, we root the discussion to its very historical context by sampling the biblical data regarding the original nature, essence, purpose and the prescribed method for its usage. As such, we undertake a historical-theological investigation for an appropriate critique of the contemporary practice being expressed in the circle of some churches in African Christianity.

However, before we proceed with our investigation on the usage of the application of the purported sacred 'anointing oil', supposing it as a marker of expressing Christian spiritualty in Africa, some definitive statements to this effect are expedient. Firstly, we used the term 'purported' to argue that what obtains today, specific to the African context of Christian religion, is not truly what the biblical text traditionally prescribed in Jewish religious consciousness. Secondly, we address the term 'African Christian spirituality' to delineate the parameters and content of our discussion. We depict here the way and manner in which African Christians express their faith, belief and practice as a means of spiritual gratification. Thirdly, we used 'fetish ancestral religion' as a recourse to the aspect of liturgical practice in African Traditional Religion (ATR). Such object serves as an expellant from the ancestors and the gods of evil spirits and misfortunes, and as a means of security and prosperity.

Spirituality is crucial to human life. Here, we agree with Kourie $(2015: 1,2)$ who thinks that the term 'spirituality' is culture-specific and has several emerging facets or variances, such as extrovertive spiritualities, which deal with concrete issues of practical life; contemplative or introvertive spiritualities, which concentrate on the inner life; integrated spirituality, which is a combination of both facets; societal spirituality, which ideally combines orthopraxis and orthokardia with the purpose of implementing an embodied practice; and a few more, forcing such increasing nuances to become domesticated as a 'catch phrase' in modern society. In Kourie's (2015) understanding:

Spirituality refers to the deepest dimension of the person ... to the raison d'être of our existence, the meaning and values to which we ascribe ... [which] can be nihilistic, materialistic, humanistic, or religious. (p. 2)

Our point of reference by using 'spirituality' is the domain of Christian religion in Africa. We therefore conceptualise African Christian spirituality as the expression of a people's connection with and their deepest longing for the immanence of divinity primarily to attend to their existential needs. Within this context, spirituality, of necessity, connects with divinity.

\section{Historical analyses of related biblical data regarding oil}

Careful readers of the Hebrew and Christian Scriptures encounter several occurrences of the oil motif. Our literary assessment of the biblical data has two purposes: to identify the motif of oil in general and to explain the motif of the prescribed sacred 'anointing oil' in particular. The historicaltheological approach enables us to argue for the unique nature, essence and usage, and to explain why there was a need for distinction between the sacred 'anointing oil' and categories of ordinary oil in vogue in the day-to-day life in ancient Jewish society. It also helps us to discover the original nature, purpose and efficacy of the sacred 'anointing oil' in ancient Jewish society. Lastly, it facilitates our understanding of the initially prescribed method for its application and the identity of those who qualified both to apply and benefit from it in Jewish sociopolitical and socio-religious contexts. We are compelled to root our assessment in the Scriptures as our authorial source material because our subject was primarily domesticated within Jewish society.

A poor understanding or perception of a text unavoidably generates an error. Accordingly, it is a truism that what the biblical texts say is not necessarily synonymous with what they mean. This, therefore, calls for an adequate hermeneutics of the ancient Jewish sacred texts regarding our subject of investigation. Two broad critical questions guide this section as we undertake to interpret the textual data serving as a framework for our discussion: firstly, why was oil an important commodity in antiquity to the effect that the biblical authors emphasised this motif? Secondly, what did the divine Author behind the human authors intend to communicate to the ancient Jewish community of faith regarding the nature, essence, purpose and efficacy of the sacred 'anointing oil', beginning with the Mosaic period?

\section{The significance and usage of oil in antiquity}

In antiquity (ancient Near East and Jewish societies) oil was derived from plant seeds or nuts, particularly, the olive oil, which was highly priced above all. Others included animal, vegetable and mineral sources (Ryken, James \& Tremper 1998:603).

It was crucial for diet as it took the place of butter and cooking fat (Gower 2005:106) and functioned as a part of the meal in Israelite society. It was a part of the ingredients mixed together with wheat flour to bake bread (Ex 29:2; 40; $1 \mathrm{Ki}$ 17:12-16; Ezk 16:13, 19). In this manner, as it is the case even today, oil was used as food and for baking and cooking (Ryken et al. 1998:603).

Besides being used in meals, oil also functioned as a source of energy to provide light to households and rooms. Hence, lamps were with oil and burning trimmed wicks to give light (Ex 25:6; 27:20-21; 35:8; Lv 24:1-2; Mt 25:3-4, $8-9)$. The LORD's Tent of meeting, Tabernacle, and later the Temple, were to hold burning lampstands for their luminary efficacy (Nm 4:16). 
Given the significant domestic function of oil in antiquity, it became necessary that oil also served as a commercial commodity that earned income for families (2 Ki 4:1-7; Ezk 27:17). It was stored for this purpose by wise families (Pr 21:20; Jr 40:10). Besides, well-priced olive oil made from olive trees was used in paying taxes (Gower 2005:105). It is likely that payment of dowry included olive oil (Gn 24:53b).

Oil was used as a lubricant in antiquity, and in this way served as a preventive mechanism. Warriors used oil to smoothen their weapons such as the sword and the spear. Shields, too, were occasionally treated with oil (2 Sm 1:21; Is 21:5). This preventive mechanism kept the leather from drying and cracking (Freeman 1998:354; Gower 2005:110) and iron from friction. Chariots also were lubricated for smooth motion.

In terms of cosmetics, people in antiquity beautified themselves with oil and other body treatments (Es 2:12; Ps 133:2; 141:5; Ec 9:8). It was rubbed 'into the skin to give it a shine and for anointing the head to make the hair shine' (Gower 2005:106). In the harsh climate that caused the skin to dry, the use of oil would help to soften and preserve the tenderness of the skin (Ryken et al. 1998:603). Of course, olive oil was mixed with other ingredients to produce aromatic perfumes that particularly people of affluence wore (Is 57:9). Even within the religious circle, the ancients were to put oil on their heads during religious fasts (Mt 6:17). Among other imageries attached to oil in antiquity, it played a significant role as the ancients were advised, instructed or guided to 'anoint the head with oil' (Ec 9:8).

Undoubtedly, healing from disease and sicknesses was crucial in antiquity and oil was 'valued for its healing properties' as it was applied to wounds (Ryken et al. 1998:603). Physical wounds were treated with oil and wine for healing, as demonstrated by the New Testament narrative of the victim of banditry (Lk 10:34). In this connection, Jewish psalmody indicates the aspect of oil serving a therapeutic role within the medical circle to treat orthopaedic disease (Ps 109:18; Is 1:6). Additionally, Christ's disciples used oil symbolically to anoint the heads of the sick for healing (Mk 6:13) - an Old Testament tradition that James later picked up on when he invited the elders of the community of faith to appropriate it (Ja 5:14).

Beyond these, the use of oil also occupied a crucial position when signing a contractual undertaking in antiquity. In the case of ancient Near East, oil was a prominent feature of the oath-curse ritual. It was used to 'ratify and solemnise commitment in diplomatic relations, business contracts, nuptial rites and the liberation of slaves' (Ryken et al. 1998:33). Specifically, in Hittite oath rituals, a person was coated with oil after which oath curses were smeared into the body. The act of smearing/anointing was self-administered to reflect 'the conditional self-imprecation assumed by the one who takes the oath', indicating internalising the oath curse (Kitz 2004:316). By implication, Kitz (2004:316-319) explains that in both Hittite and Akkadian oath rituals, an oath violator would not merely suffer material lack and social estrangement, but the skin upon which oil was smeared to soften it would instead cause it to suffer vulnerability by attracting harm such as skin affliction with disease, dryness, dullness, scaliness and even flakiness.

Oil equally served a figurative social function in antiquity. The poetry of the Psalmist and the prophets, in the case of Jewish society, also assume the metaphor of oil as representative of joyful expression (Ps 45:7; Is 61:3; Heb 1:9). Oil is conceived of as flowing from rocks (Dt 32:13; Job 29:6), indicating fertility or prosperity (Ryken et al. 1998:603). It is also portrayed as a source of happiness and gladness that makes the human face to shine (Ps 104:15). In addition, the records of the New Testament suggest that guests were honoured by oil being poured onto their heads ( $\operatorname{Lk} 7: 46)$, thus connoting honour and hospitality. This means the feet of travelling or invited guests were washed and anointed or rubbed with oil (Ryken et al. 1998:603).

Oil played a significant role in the cultic-political space in ancient Near East (ANE). The idea of placing the obligation of restoring a dilapidated temple in Mesopotamia rested upon an anonymous future prince. Another instance is found in Esarhaddon's inscriptions surrounding the event of the Akkadian temple rededication, suggesting that the restorative refurbishing required that the entire building structure was dipped in oil as a sign of anointing it to make it radiant (Avalos 1998:507-511).

Lastly, precious oil, sometimes mixed with aromatic spices, was used as a preservative for the embalmment of corpses. This is depicted clearly by the drama that played out between Jesus and the woman who poured oil on him (Mt 26:6-13; Mk 14:3-8; Lk 7:36-38, 46). A Christological reading of the woman's act is that she was preparing him for his burial. The woman's action, unknown to her, was a prophetic prefiguration of a typical burial ritual (Smith 2013:32). Some women, too, went to anoint the body of Jesus when they were restrained because he had risen (Mk 16:1-6). The diverse uses of oil discussed above indicate its indispensability to life in antiquity (ANE and Jewish).

\section{The uniqueness and efficacy of anointing oil in the biblical texts}

The idea and practice of anointing with oil first originated in the Pentateuch with Jacob when he poured oil upon a rock/ pillar at Bethel. This act was in commemoration of the spot of his dream, indicating his recognition of the presence of the Divine there (Gn 31:13). The mention of Bethel within the narrative context of Jacob's flight from Laban may likely be a confirmation that his ancestral deity 'was now unmistakably calling him back to the land of Canaan' whence he had fled for safety (Payne 1986:135). It may well rather be the assurance of the presence of the God of his father and grandfather with him. Jacob needed such an assurance as a fugitive. However, the specific detailed instructions regarding the nature, essence, purpose, uniqueness and the preparation 
and application of what would later be known as the prescribed sacred 'anointing oil' in Jewish tradition are documented in the books of Exodus, Leviticus and Numbers.

The second occurrence of the idea of 'anointing' with an oily substance is seen in Yahweh's specific directive to Moses. He was instructed to prepare a special oil for sacred use (Ex 25:6; $35: 28)$. It was prepared specially for use beyond the ordinary day-to-day uses on account of its unique formula. Special, finest, best quality spices such as liquid myrrh, fragrant/ sweet-smelling cinnamon, fragrant calamus/aromatic cane, cassia and olive oil were blended in preparing the divinely prescribed sacred 'anointing oil' for use in the sacred space (Ex 30:22-33). This specially prepared sacred 'anointing oil', very obviously, was made from 'rare and expensive scented spices', likely obtained from Persia, India and Arabia which 'were renowned for the export of aromatic perfumes' (Ryken et al. 1998:604). The inescapable import of the nature of this specially prepared oil was its unique formula, quite different from the mundane type.

\section{The uniqueness of the sacred anointing oil}

It is crucial to discover the essence and purpose of the prescribed sacred 'anointing oil' in Jewish tradition. The uniqueness of the special oil lies in its being sacred. Consequently, people were forbidden from preparing its replica. Such oil was to be applied only to the people Yahweh had chosen and engaged in his service, cultic or political, and the innate articles to be used in service to him. The nature of the specially prescribed recipe for the sacred 'anointing oil' and the method of its preparation make it fundamentally sacred with its restricted usage (Sanderson 2001:127). In addition, Gordon (1986) explains why restriction was placed on its abuse by replication or misuse. Spices were traded considerably in ANE and their domestic use for cooking and as cosmetics was also common. This necessarily called for the need to guard the distinctiveness of the sacred blend of these spices (Gordon 1986:181) in Jewish society. Failure to meet the divine imperative regarding replication and abuse was detrimental to any defaulter (Ex 30:31-33). As a safeguard, the Jews were, by their perception, attitude and behaviour, to treat the sacred 'anointing oil' as sacrosanct.

The ingredients that made up the content of this sacred 'anointing oil' deserve attention. The Hebrew word ro's for 'head', 'crest', 'top', 'beginning', used as a descriptive term in Exodus 30:22, attracts nuanced translations such as 'best' (CJB), 'chief' (ASV, ERV), 'choice' (NET, NLT, TNK), 'finest' (CSB, ESV, NIV, NJB, NRSV), 'principal' (GNV, KJV, YLT) and 'quality' (NKJV). These nuanced translations are used to describe another Hebrew word, bośem for 'spice', understood as Balsam shrub or Balsam oil that produces a sweet-smelling perfume when blended. This is clearly indicated that the quality of spices selected to prepare the sacred 'anointing oil' was of no ordinary category, but the best and highly priced commodity used in honour of the divine Giver and the causation of the production of plant crops and other agricultural products. Accordingly, the Divine demands the first and best because he deserves the best of exhibited attitude and character, relationship and worship from the community of faith.

The term 'anointing oil' came into vogue in Israelite religious tradition on account of its sacred nature and function within the sacred space. To anoint human beings or innate objects literally refers to the act of pouring or rubbing oil onto a person or thing (Ryken et al. 1998:33). The Hebrew verb $m \bar{a} s ̌ a h$ for 'anoint', according to BDB, means 'smearing', 'anointing', probably expressing the Aramaic idea of wiping or rubbing with a stroke of the hand (Brown, Driver \& Briggs 2006:602-603). This resonates with the ATR's act of sprinkling specially mixed water solution, or the blood of slaughtered fowl such as those obtained amongst the Mhiship, Mupun, Mwahavul and Ngas tribes of Jos, Plateau of Nigeria (Danfulani 2012:116-118). A priest would normally dip a bunch of fresh leaves into such special cultic water or blood and sprinkle it on the wall of a house, on a certain property or area and on an object or person for purification, exorcism from evil spells or for protective insulation from evil and demonic possession.

Mounce (2006:23-24) draws attention to the dual understanding of the word māsăh. In its non-technical sense, the Hebrew verb expresses the idea of 'rubbing' with a liquid, such as painting a house, rubbing a shield with oil or rubbing the body with oil as a cosmetic lotion. The technical sense, however, means 'to anoint', with specific focus on the religious aspect. Accordingly, innate religious objects such as the Tent and Tabernacle, with all their articles, in the Old Testament were anointed on this ground and so they were rendered holy (Ex 30:26-29; 40:9-11). Humans, too, were anointed to signify 'their undertaking special responsibilities' as people set apart for special service to God. It was the duty of the priest in Israel to assume this role.

\section{The efficacy of the sacred 'anointing oil'}

It is quite appropriate to state the efficacy of the prescribed sacred 'anointing oil'. The act of 'anointing' such people (literally by God himself but mediated by his chosen human representative instrument) not only set them apart for service but also conferred authority on them for the service (Mounce 2006:24; Ryken et al. 1998:33). The concept of 'anointing', then, has recourse to the 'practice of applying oil or perfumed oil upon persons or things' predominantly domesticated in the historical books in direct reference to the monarchy and priesthood (Harris 1987:45). Used within the Jewish context, the verb refers to the act of consecration, a setting apart to an office, either for political service in the case of kings or for ecclesiastical service in the case of priests (Brown, Driver, Briggs 2006:603). Regarding the reported incident in the Markan narrative of the woman who poured oil on Jesus at Bethany (Mk 14:3, 6-9), Smith (2013:34) deduces its burial, royal and priestly purposes, hinted at in the narrative. 
The act of ' $[a]$ nointing was performed in the ancient world for a variety of reasons' (Smith 2013:32), particularly within Jewish political and religious spaces. One amongst the principal functions of the sacred 'anointing oil' in Jewish liturgical cultic practice was its consecrational efficacy (Ex 29:7, 21; 37:29; 40:9-11). Certain cultic spaces and innate articles were consecrated by anointing them with the sacred 'anointing oil' to make them ready for the performance of religious rituals. Political and cultic officials, too, such as the prophets, priests and kings, were necessarily consecrated with the sacred 'anointing oil' (Lv 10:7). Their prominent functions in Jewish society explain such setting apart by means of their anointing. It was the role of prophets to speak to society on behalf of God, the priests to represent society to God and the king to establish divine laws in society (Gower 2005:107). Anointing such persons with the sacred 'anointing oil' indicates Yahweh's choice, conferred authority, blessings and preservation of them consequent upon their obedience to his laws (Ryken et al. 1998:33). The nuance of such symbolism is a clear indication of the coming of the divine Spirit upon God's servants for the assigned task (Harris 1987:45).

The second area of the efficacy of the sacred 'anointing oil' resided in its liturgical prescription, thus assuming a sacral significance in religious worship (Ryken et al. 1998:604). Oil mixed with other specified ingredients, such as with finest flour and incense, was offered to Yahweh as pleasing fragrant grain offering. This was an aromatic burnt offering acceptable to Israel's deity ( $\operatorname{Lv} 2: 1-2,14-16 ; 6: 21)$. Out of the five categories of offerings in Jewish rituals, the inclusion of olive oil in the grain offering was deliberate. This was to be a sign of the offerer's recognition of Yahweh's goodness and provision, and as a voluntary act of worship and devotion to him (Baker 2011:164).

The third point of efficacy of the sacred 'anointing oil' in antiquity as restorative also 'prefigured prominently in ritual purification' (Ryken et al. 1998:604). As an aspect of the cultic function in Israelite religion, its serving as a purifying agent for people who had been healed from some disease was extant for restoration (Lv 14:10-18, 26-29). Sick people were normally isolated in an isolation camp outside the city away from family, friends and the general public. Those who recovered were required to undergo religious ceremonial cleansing. Certain items, amongst which was olive oil, were required for the priest's purification rites.

Another efficacy of such specially prepared oil also served an elective and confirmatory political purpose. This suggests that a coronary import of using the sacred 'anointing oil' occupied a crucially significant space in the Jewish tradition of monarchial enthronement (Jdg 9:6-9). For instance, both Saul and David were anointed by Samuel with the sacred 'anointing oil' to become monarchs of the United ethnic national Israelite society (1 Sm 10:1; 16:1, 13; Ps 89:20). Also, Solomon was anointed king over Israel by Zadok (1 Ki 1:39) and Jehu over Israel, the northern kingdom, by the pouring of oil over his head (2 Ki 9:1-10). Interpreted against this backdrop of royalty, the concept of 'anointing' firstly depicts the rite of divine choice of the king-designate by the priest pouring oil upon him, and secondly, it depicts the rite of the ceremony for the king's public installation and enthronement by the people (Weisman 1976:380, 382). This portrayal of royalty is evident in the Davidic confession of Yahweh's preservation of his life and his public honour (Ps 23:5; 89:20; 92:10). Even in the Egyptian context, Egyptologists have debated whether the Pharaohs ever used oil to anoint their officials as a means of installing them into office as a sign of their invested official authority. However, Thutmosis III is acknowledged to have anointed an official into office according to El-Amarna Letter (EA) 51 (Thompson 1994:15-25).

\section{Evaluating the contemporary African Church's contextual usage of the anointing oil in resonance with the theological implications of the biblical data}

We noted previously that, since its birth by the emergence of the New Testament church, Christianity has adapted to different cultural and social contexts where it found itself. As Kourie (2015:1) reasons when discussing religious spirituality and mysticism, it is a truism that ' $[t]$ he essential contextuality of spirituality and mysticism is to be found within the parameters of a given society, and therefore cannot be examined in a vacuum'. The presence of the Christian faith in Africa was introduced by the presence of Jesus and his family in Egypt, North Africa (Hs 11:1; Mt 2:13-19; Ac 2:7-12), then by the infectious theological contributions of the African Fathers in the Antiochean and Alexandrian schools in North Africa (Isichei 1995:13-44; Parratt 1997:1), further by the Portuguese Catholics in the Southern Saharan African region in the late 15th century and, lastly, in the West African region in the 19th century by the European and American missionaries (Isichei 1995:74-97, 264-298; Parratt 1997:1). Since then, Christian theology, doctrines, sacramental liturgical order, worship and its general outlook became adaptive to the various regional African contexts.

Amongst the symbolic representations of the liturgical practices borrowed from the Old Testament tradition into African Christianity is the use of the prescribed sacred 'anointing oil'. Not all church traditions practise the use of it, but those churches that engage in its practice misunderstand the original essence and intention, and the application of the 'anointing oil'.

As such, the contention regarding whether Christians should still use what the Old Testament had prescribed as the sacred 'anointing oil', also partially stated in the New Testament, is ongoing. Whilst the tension regarding the question of functional cessation or the material continuity of the sacred 'anointing oil' within the Christian circle still attracts attention in some Christian quarters, what is a worse scenario is the 
manner in which the purported 'anointing oil' is being used in some churches in Africa today. Against this background, we sought to establish that the increasing attention being given to the purported 'anointing oil' and the manner in which it is being used today within African Christian community is not a true reflection of its original intent. We also claim that it does not really express authentic Christian spirituality. Rather, it is a mere display of fetish ancestral religion. This readily accounts for why the 'anointing oil' is gaining more prominence than the Christ of the gospel in African Christianity.

This section is guided by the following questions: how has the African version of Christianity conceptualised the essence and purpose of the concept of the Old Testament sacred 'anointing oil' in its purported usage? What is the prevalent methodological framework adapted for its application and what theological impasse does this pose for Christian spirituality and pastoral theology in Africa? What accounts for the quest and thirst for this religious symbolism by some of the African churches?

The biblical texts, as sacred or religious texts, undoubtedly, have emerging theological imports for all generations. However, the quest by modern interpreters to decipher and comprehend properly its ancient originally intended meaning and their effort at its proper and adequate application is not only crucially important but also sometimes an uphill task.

As such, readers should reflect carefully on the biblical data above and consider what it portends for the contemporary theological understanding of the application of the purported 'anointing oil'. Does the efficacy of the prescribed ancient sacred 'anointing oil' still hold any significance for Christianity today? Two major contemporary implications regarding the manner in which the purported 'anointing oil' is venerated are obvious: how this theological error affects Christian spirituality in the church in Africa, and how it poses a great threat to pastoral theology, making it more tasking for pastoral ministry.

\section{The theological implications for Christian spirituality in Africa}

Nmah (2013:35) is right in positing that ' $r$ ]eligion is a reality in human experience and pervades through life'. By implication, something is lacking when humans fail to offer worship to some sort of deity. Converted African Christians, arising from their already homogeneous traditional religious background, seek to use biblical symbols to express their belief and faith, one amongst which is their use of the purported 'anointing oil'. This is not surprising; the religious contexts of the African peoples unavoidably account for the misconceptualisation, misinterpretation and the distortion of the essence and efficacy of the Old Testament-prescribed sacred 'anointing oil' and its application within religion. Undoubtedly, the African continent is an impressively boisterous religious one and its peoples, too, are vexingly religious. As the Kenyan scholar John S. Mbiti (1990:1) succinctly describes their religious climate, 'Africans are notoriously religious, and each has its own religious system with a set of beliefs and practices'. The traditional ancestral religious worldview of the Africans obviously also largely explains why a new interpretation and mode of usage assigned to the purported 'anointing oil' is extant and never goes away in the practice of some African churches.

What we attend to here is the question of the relevance to African Christian spirituality of the purported 'anointing oil' that is gaining momentum in almost every church denomination (mainline and Pentecostal alike). We undertake to unveil the theological injury that such erroneous conceptualisation and application has caused for Christian theology and Christian spirituality in Africa. We contend here that the initially initiated ancient sacred 'anointing oil' does not have any efficacy for Christian spirituality today as it was in antiquity. Even the mere attempt at contextual contemporisation of its textual spirit possesses risky doctrinal and theological hiccups.

The contemporary reality of the expression of religion globally seems to have more followers in the face of difficulties. Baloyi (2014:4) reports the case of Limpopo province in South Africa where some Christians seek sangomas and traditional healers during difficult times, particularly to ward off witchcraft. The presence of soothsayers and disguised spiritualists in the church, and the increasing presence of fake prophets in African Christianity, readily makes desperate Christians seeking for spiritual solution to their existential needs easy prey. This then explains why, within the Christian religious context in Africa, the concept of what was known as the sacred 'anointing oil' in the Old Testament is now being used as a healing balm, as an exorcist's expellant, as a protective spell and, in some churches, as a means of fortune, wealth generation and prosperity. Within the Nigerian context also, some proponents claim that the purported 'anointing oil' is a medium of transference of spiritual powers. Therefore, their members are directed to leak, drink, apply on the head, apply on some objects of personal possession such as clothes, cars, houses, electronics, cushions and so on, and rub on the palms the purported 'anointing oil' the Man or Woman of God has offered prayer upon to derive its efficacy (Nwaomah 2009:57, $60)$. Such is a clear case of a modernised and spiritualised reform of ATR's ritualistic libation and invocation of the spirits. Only fetishism could account for the hermeneutical and theological import of such heresy.

Undoubtedly, there are motivations for this distorted conceptualisation and application of such a biblical cultic symbol. According to Nwaomah (2009:50), one of the reasons that explains why many contemporary African Christians crave after the purported modern 'anointing oil' is 'their quest to appropriate the providences of God in their lives, endeavo[u]rs, and in order to protect their possessions'. Quite glaringly in the African context of religion, ' $[t]$ he 
patronage and search for solution to problems through ATR is still as visible as it was several decades ago' (Akinmayowa \& Rahman 2019:35). The perpetrators of such Africanised fetish symbols Christianise it by invoking prayers upon the oil to make worshippers believe in 'the mediating power of the pastor acting as God's conduit of blessings to the Christian believer' (Magezi \& Banda 2017:4). In fact, smearing the purported 'anointing oil' blessed by the Man/Woman of God around one's residence is believed to expel demons and ensure the safety of the occupants (Nwaomah 2009:58). This has become increasingly apparent even today because of what Kato (1985:11) had described years ago as 'theological anaemia'. Anaemic theological expression and practice emerge because of biblical and theological ignorance and because of a refusal to accept the biblical fact and thereby seek to know and live in the truth by its perpetrators.

Regarding existential life in the case of South Africa, Mouton (2014) argued that the:

[C] urrent disruptive phenomena and psycho-social challenges communities are faced with necessitate a more concerted effort in the pastoral care and counselling domain to shift towards a systemic and community-directed approach. (p. 93)

As one who had years of personal experience in the field of practical pastoral ministry, Mouton is quite correct. Yet, such negative community experiences are aggravating in society for want of a truly rooted Christian theology in the hearts of members of the community of faith, who should, in turn, become light-bearers to their society. Mouton's (2014:103) concern is basically anthropologically focused as such physiological concerns are to 'compel pastoral care-givers and theologians to position themselves along the praxis of a compassionate God who takes seriously the human predicament of suffering and vulnerability'.

What this instructive theological deficiency portends for the Christian faith, particularly given the complex African experience, is what the Burkina Faso theologian, Tite Tiénou (1990:22), identified three decades ago. According to him, 'much of practical evangelical Christianity in Africa is terribly syncretistic' (1990:22). Along this line of thought, he explains what he calls the 'many facets' of syncretism such as unwitting syncretism, which comes about as a result of the inadequate teaching of the Scriptures, practical syncretism in which a professing Christian seeks help from a specialist of traditional religion or carries on the body some protective amulet and theological syncretism. As he points out the theological and ecclesiastical implications, '[ $p$ ]ractical syncretism will weaken Christianity even if our official theology remains orthodox' (1990:22). A frequent return to ancestral spirits and religion via spiritualised and Christianised objects and symbols is one aspect of such weakening. Some Christians secretly easily revert to or patronise ATR and the traditional practices whilst still keeping the Christian faith, as Akinmayowa and Rahman (2019:35) argued. The cause is seeking for solution to their lived existential needs because they still have cultural attachment to the traditional practices.
Even years before Tiénou, Kato (1985:11) had already identified this danger when he observed that biblical Christianity in Africa was being threatened by syncretism. As an antidote, he proposed that such a spiritual battle for the church in Africa would have to be fought on theological grounds. This puts a truly Christian theology as well as pastoral theology at the edge and on their toes - for the problem must be adequately addressed biblically and theologically.

The perpetrators of the use of the purported 'anointing oil' today argue for its continuity in the New Testament. Even then, of the five figurative occurrences of chrio for 'anointing' with reference to divine commissioning, one referring to the church and four referring to the empowerment of Christ by the Holy Spirit, 'the use of oil or any external substance as the instrument of anointing is excluded' (Nwaomah 2009:50). Even the nine occurrences of aleiphō in the New Testament are contextually nuanced differently with regard to its meaning. Only its reference to healing in Mark 6:13 and James 5:13-16 becomes contentious. In these cases, reference was to an Old Testament practice that was already fizzling out of use.

Here, then, a distorted hermeneutical understanding of the Old Testament concept of the prescribed sacred 'anointing oil' and its adulterated and deformed theological essence via its expression in some churches today in Africa only goes to show the shallow hermeneutical and theological education of its champions. Whilst some of them were never trained in Christian theology, others who claim to have received some level of training appear either half-baked or as intentional fraudsters. However, it is also a truism that the manner in which the white missionaries presented the Christian gospel to Africa in its white cultural garment without a careful recourse to the unique African context, unfortunately, 'failed to penetrate to the heart of African personality' (Parratt 1997:3). This initial weakness still hunts after the hermeneutical, theological and doctrinal minds of most professing Christians in modern Africa.

As a consequence, the use of the purported 'anointing oil' in the church today appears more fetish than factual. This is a redefined form of ATR belief in the expellant spirit inherent in magical liquids and amulets, having recourse to its exorcistic and protective import. The greatest threat to biblical Christianity and Christian spirituality in Africa of using the purported 'anointing oil' for fetish purposes is its injurious heresy. A careful observer of what plays out in African Christian spirituality would admit that 'heresy is vigorously competing for space in African Christianity today' (Biwul 2019:44). Heresy, according to Alister McGrath (2009:33), is not unbelief but 'a form of that faith that is held ultimately to be subversive or destructive, and thus indirectly leads to such unbelief'. Described as the greatest onslaught on Christian spirituality in Africa today (Biwul 2019):

Heresy is going against the established fundamentals of the Christian faith by distorting its doctrinal paradigm and corrupting its truth. ... [heresy] is an intentional erring or a departure from sound biblical, doctrinal and theological truth with the goal of distorting, corrupting, and subverting biblical truths. (p. 266) 
Heresy has a detrimental effect on Christian spirituality. Not only does it produce shallow Christian spirituality but it also amounts to a distortion of Christian expression. Mbewe (2017:2) makes this clear when he points out the effects of such shallowness, explaining that Christians submitted to heresy will lack spiritual depth and firm roots. Consequently, they 'are easily swept away when cults come to town'. This clearly suggests that such shallow Christians are unable to handle the raging storms of life with Christian maturity.

\section{Theological implications for pastoral theology}

It is no exaggeration to claim that all theologies end at the doorsteps of pastoral theology. As an aspect of practical theology, this category of theological expression is actively engaged in the field of what Tiénou (1990) calls 'popular theology'. He explains this to mean the kind of (Tiénou 1990):

$[T]$ heology expressed in hymns, in preaching, and in the ordinary counsel given by pastors and other spiritual leaders on a day-today basis ... [arguing that it is this kind of] theology that takes root in the hearts of the people in Africa. (p. 50)

What, then, do people within the domain of pastoral theology make of the biblical data vis-à-vis the glaring challenge of a gradually changing African Christian worldview regarding the use of the purported 'anointing oil'? The various aspects of pastoral care - much more, the pastoral ministry as a whole - are quite burdensome. It is an all-encompassing task. Despite this, some uninformed parishioners consider it as merely a sacrificial service that should either not be remunerated or be less remunerated. This informs Magezi and Banda's (2017) call for balance between ministry as a sacrificial act and appropriate economic remuneration for the upkeep of pastoral ministers. As Dillen (2017:4) admits, it is both self-sacrificing and selfgiving. Persons who have truly sensed the divine call upon them for this ministry naturally seek to empty themselves into others, sacrificing their comfort and risking their lives as well for those of other people.

The challenges of pastoral theology go far beyond the mere intrusive, disruptive and traumatising effects of the phenomena of life (Mouton 2014:92) into the domain of the necessity for consistent teaching and periodic re-echoing of a correct Christian theology and doctrine for the community of faith. We seek here to articulate the argument that the manner in which many churches in Africa today construe and apply the purported 'anointing oil' as an expression of Christian spirituality is merely a blatant display of fetish ancestral religion that inescapably has several detrimental theological and doctrinal effects on Christian spirituality in Africa. In this regard, Tiénou (1990:22) admits that a syncretistic practice of Christianity becomes an important pastoral problem.

Even those proponents who argue in support of such a practice on the strength of James 5:13-15 fail to respect its cultural and historical context. Only Hebrews and James used the LXX exclusively as the most Jewish epistles amongst the New Testament writings (Osborne 2006:324). Against the
Old Testament context where 'the significance of oil was very familiar to the Palestinian Christians that James was writing to' (Nwaomah 2009:54), his focus was more on prevailing contextual, psychological and emotionally traumatic imbalances than on the customary therapeutic effect of oil on physiological health; furthermore, it relates to spiritualisation as is seen today. On this warrant, Nwaomah could be correct in his conclusion. The potency of James's prescription (Jos $5: 14,15)$ to anoint the sick with oil, a symbolised agency of the Holy Spirit, resides not in the oil itself but in faith in the power of God to heal through prayer (2009:56).

The problem becomes complex when the centre of attraction in Christianity shifts from the Divine. Baloyi (2014:7) reports that in their attempt to respond to people's existential issues/ challenges, pastoral caregivers from the mainline churches and most charismatic preachers sometimes devote more time to dealing with issues of witchcraft and demon casting than to preaching the true Gospel. According to this author, ' $[i]$ n some churches, demon casting and witchcraft have become the centre of worship services which usually attract many people'. Such an unfortunate theological shift reduces Christianity to the level of humanity, thereby robbing it of its inherently embedded divinity. However, in his Pastoral Preaching, Mbewe (2017:1) says the goal of sound biblical preaching of the Gospel is to produce people who assuredly know God and are living life to glorify him, and then to build such people for God. This is unavoidably necessary for a deeply rooted Christian spirituality on the ground that the core of Christianity is all about the God of Revelation; the call to the Christian faith is all about loyalty to the Christ of the cross; and the confession of Christianity is all about living consistently in reverence towards him and his glory. This is what pastoral theology should strive to implant and preserve in the individual and incorporate into the life of members of the Christian community.

However, an obvious impediment to quality Christian spirituality and therefore a serious challenge to pastoral theology is the ongoing low literacy level of African Christians. Not many worshippers of the Christian faith intentionally seek theological education for a better grasp of the biblical text. Many will only readily say 'yes' to whatever the 'Man or Woman of God' or the 'Pastor' says, whether it is biblically correct and theologically sound or not. In what Osborne (2006:329-330) describes as a reorientation of a text for a new meaning, these perpetrators, some ignorantly though, deliberately modify the authorial intention for a different recension of the text. On this ground, the Berean Christian model becomes a far cry away from reality (Ac 17:11-12). We are in complete agreement with Nmah (2013) who calls for the need to strive for quality theological education that develops character and good ethics in every Christian worshipper in the Nigerian context of Christian spirituality. By extension, African Christians should become aware of what is a true and transforming missional Christianity so that they can personally reflect 'deeply about their own theological engagement' and thereby ably 'champion their ideas intelligibly and spiritually in writing, character, learning, and speaking' (Nmah 2013:35). 
It has never been the use of cultic symbolism that causes a deepened spirituality in the church but rather a completely transformed life that lives in consistent obedience to the tenets of the religion enshrined in the biblical text. Accordingly, unless pastoral caregivers settle down to give church members the basics of true Christian transformation and maturity in faith, character, life and personal conviction, more amongst them will believe and accept just anything that is thrown at them, even mundane things worse than the assumed efficacy of the purported 'anointing oil'.

\section{Conclusion}

Motivated by a theological and pastoral concern, this article endeavoured to address the contemporary application of the Old Testament-prescribed sacred 'anointing oil' within the Christian community, questioning whether such practices truly spring from an adequate understanding of its biblical context. It argued that the expression of Christian spirituality will always be in error and stand at the risk of heresy when readers forcefully eclipse the needed adequate contextual understanding of the biblical texts. Readers should not easily lose sight of the fact that biblical texts, as literary and sacred as they are, are first and foremost contextually defined texts to contextually situated first readers.

Therefore, not everything that readers encounter in the biblical texts is relevant for the contemporary experience of Christianity. Whilst some events and practices are merely descriptive, others are obviously prescriptive. What is binding for all generations then is the prescriptive rather than the descriptive elements. The crucial question readers should come away with then is whether the use of the sacred 'anointing oil' as it featured in the Old Testament is a biblical description or a prescription for use by all generations of the community of faith. What is fundamental also is whether the supposed Christian perpetrators of such fetish practices can honestly defend their application of the purported 'anointing oil' from Scriptures to argue for its relevance for Christianity. Would their case also stand on sound biblical, theological and moral ground?

When we speak about transformed people who propounded Christian theology in the New Testament, Apostle Paul ranks next to Jesus, and this is so only because the latter possesses both divinity and humanity. We recall from the accounts of the four gospels that Jesus himself never gave any express prescriptive directive for the use of the 'anointing oil', nor did he even refer to it, much less Paul. If such an Old Testament cultic tradition still holds significance for the New Testament church, one is puzzled that Paul never gave credence to it in all his epistles.

\section{Acknowledgements Competing interests}

This is a personally motivated and self-sponsored research. Accordingly, the author declares that there were no financial or personal contracts which may have inappropriately influenced the writing of this article.

\section{Authors' contributions}

I declare that I am the sole author of this research article.

\section{Ethical consideration}

This article followed all ethical standards for a research without direct contact with human or animal subjects.

\section{Funding information}

This research received no specific grant from any funding agency in the public, commercial or not-for-profit sectors.

\section{Data availability statement}

Data sharing is not applicable to this article as no new data were created or analysed in this study.

\section{Disclaimer}

The views and opinions expressed in this article are those of the author and do not necessarily reflect the official policy or position of any affiliated agency of the author.

\section{References}

Akinmayowa, A. \& Abbas, A.R., 2019, 'Return to African traditional religion after conversion to Christianity or Islam: Patronage of culture or religious conversion?', Ilorin Journal of Religious Studies (IJOURELS) 9(1), 27-36.

Avalos, H., 1998, 'Daniel 9:24-25 and Mesopotamian temple rededications', Journal of Biblical Literature 117(3), 507-511. https://doi.org/10.2307/3266446

Baloyi, M.E., 2014, 'A pastoral examination of the Christian Church's response to fears of and reactions to witchcraft amongst African people in the Limpopo province of South Africa', HTS Teologiese Studies/Theological Studies 70(2), Art. \#1317, 1-9. https://doi.org/10.4102/hts.v70i2.1317

Baker, K.L. (ed.), 2011, The NIV study Bible, Zondervan, Grand Rapids, MI.

Biwul, J.K.T., 2019, Expository preaching in Africa, ACTS Publishers, Bukuru.

Brown, F., Driver, S.R. \& Briggs, C.A., 2006, The Brown-Driver-Briggs Hebrew and English Lexicon, Hendrickson, Peabody, MS.

Danfulani, U.H.D., 2012, 'Kum: Traditional religion', in U. Habila, D. Danfulani \& S.U. Fwatshak (eds.), Celebrating Njinkook: Studies in the history and culture of the Mupun of the Jos Plateau in Nigeria, vol. 1, pp. 84-141, Lynx Communications, the Mup
Kaduna.

Dillen, A., 2017, 'Beyond a sacrificial spirituality: Enhancing flourishing pastoral ministers', HTS Teologiese Studies/Theological Studies 73(4), a4694. https://doi. org/10.4102/hts.v73i4.4694

Freeman, M.J., 1998, The new manners \& customs of the Bible, Bridge-Logos, Alachua, FL.

Gordon, R.P., 1986, 'Exodus', in F.F. Bruce (ed.), The international Bible commentary, pp. 149-187, Marshall Morgan \& Scott, Basingstoke.

Gower, R., 2005, The new manners \& customs of Bible times, Revised and Updated, Moody Bible Institute, Chicago, IL.

Harris, R.L., 1987, 'Anointing', in E.H. Harrison (ed.), Baker's dictionary of theology, p. 45, Baker, Grand Rapids, MI.

Isichei, E.A., 1995, A history of Christianity in Africa: From antiquity to present Eerdmans, Grand Rapids, MI \& Africa World Press, Inc., Lawrenceville, NJ.

Kato, B.H., 1985, Biblical Christianity in Africa, Africa Christian Press, Achimota.

Kitz, A.M., 2004, 'An oath, its curse and anointing ritual', Journal of the American Oriental Society 124(2), 315-321. https://doi.org/10.2307/4132218

Kourie, C., 2015, 'Weaving colourful threads: A tapestry of spirituality and mysticism', HTS Teologiese Studies/Theological Studies 71(1), Art. \#3023, 1-9. https://doi. org/10.4102/hts.v71i1.3023

Magezi, V. \& Banda, C., 2017, 'Christian ministry and theological education as instruments for economic survival in Africa', HTS Teologiese Studies/Theological Studies 73(3), 4545. https://doi.org/10.4102/hts.v73i3.4545

Mbewe, C., 2017, Pastoral preaching: Building a people for God, Langham Preaching Resources, Cumbria. 
Mbiti, J.S., 1990, African religions and philosophy, 2nd edn., reprint, 2008, Heinemann, Gaborone.

McGrath, A., 2009, Heresy, SPCK, London.

Mounce, W.D. (General Ed.), 2006, Mounce's complete expository dictionary of old \& new testament words, Zondervan, Grand Rapids, MI.

Mouton, D.P., 2014, 'Communities facing disruption: The need to shift from individual to community paradigms in pastoral care', Acta Theologica 34(1), 91-107. https:// doi.org/10.4314/actat.v34i1.6

Nmah, P.E., 2013, 'Theological education and character formation in Nigerian Christianity: A reflection', African Research Review, An International Multidisciplinary Journal, Ethiopia 7(1), Serial No. 28, 34-46. https://doi.org/10.4314/afrrev.v7i1.3

Nwaomah, S.M., 2009, 'Anointing with oil in African Christianity: An evaluation of contemporary practices', Journal of Adventist Mission Studies 5(2), Art. 7, 50-64.

Osborne, G.R., 2006, The hermeneutical spiral: A comprehensive introduction to Biblical interpretation, Revised and Updated, Inter-Varsity Press, Downers Grove, ML.
Parratt, J. (ed.), 1997, A reader in African Christian theology, rev. ed., reprint, 2004 Baraka Press and Publishers, Kaduna.

Payne, D.F., 1986, 'Genesis Chapters 12-50', in F.F. Bruce (ed.), The international Bible commentary, pp. 123-148, Marshall Morgan \& Scott, Basingstoke.

Ryken, L., James, C.W. \& Tremper, L. (eds.), 1998, Dictionary of Biblical imagery, Inter-Varsity Press, Downers Grove, IL.

Sanderson, J.E., 2001, 'Exodus', in M.D. Coogan (ed.), The Oxford Annotated Bible, 3rd ed., pp. 82-141, Oxford University Press, Oxford.

Smith, J.M., 2013, "'She hath wrought a good work": The anointing of Jesus in Mark's Gospel', Studies in the Bible and Antiquity 5, Article 4, 30-46.

Tiénou, T., 1990, The theological task in Africa, 2nd edn., Africa Christian Press, Achimota.

Thompson, S.E., 1994, 'The anointing of officials in ancient Egypt', Journal of Near Eastern Studies 53(1), 15-25. https://doi.org/10.1086/373652

Weisman, Z., 1976, 'Anointing as a motif in the making of the Charismatic King', Biblica 57(3), 378-398. 